\title{
Interface entre Midiatização e Mercado Religioso a partir do estudo da emissora católica Rádio São José
}

\author{
Interface between Mediatization and Religious Market \\ from the study of the Catholic broadcaster Rádio São José
}

Antonio Carlos Sardinha*

Marcos Vinicius de Freitas Reis**

Danilo Silva de Oliveira ${ }^{* * *}$

$\underline{\text { https://doi.org/10.29327/256659.12.1-15 }}$

\begin{abstract}
Resumo
O artigo procura apresentar uma análise sobre a inserção da Rádio São José no cenário midiático religioso amapaense, observado sob uma perspectiva histórica e conceitual que envolve pensar esse campo em um cenário de concorrência religiosa e midiatização. Para tal, apresentamos uma abordagem histórica que observa a comunicação na interface com a Igreja Católica, destacando as perspectivas comunicacionais que orientam os protocolos de comunicação dessas instituições religiosas com a sociedade. Por meio da análise das entrevistas com atores que integram a Rádio São José e da grade de programação, indicamos as matrizes gerais que orientam a ação midiática deste veículo no Amapá. Como considerações gerais, destacamos na atuação da Rádio São José a predominância de um modelo de comunicação que privilegia o fazer, na apropriação instrumental dos meios de comunicação em um processo educativo pela mídia voltado à evangelização do tipo difusionista da doutrina da Igreja, que se distancia dos desafios conceituais, técnicos e políticos observados em estratégias e políticas de comunicação que marcam a relação do campo religioso e do campo midiático em um contexto de concorrência no mercado religioso.
\end{abstract}

Palavras-chave: Comunicação. Religião. Midiatização. Mercado Religioso. Rádio São José. Amapá.

\footnotetext{
* Professor do Curso de Especialização em Estudos Culturais e Políticas Públicas (PCULT) e do Programa de Mestrado Profissional em Ensino de História da Universidade Federal do Amapá (UNIFAP). Doutor em Comunicação, integra o Grupo de Pesquisa Estudos Interdisciplinares em Cultura e Politicas Públicas e o Observatório da Democracia, Direitos Humanos e Políticas Públicas. E-mail: sardinhajor@yahoo.com.br

** Docente do Curso de Especialização em Estudos Culturais e Políticas Públicas (PCULT), do Mestrado Acadêmico em História Social (UNIFAP) e do Mestrado Profissional em Ensino de História da Universidade Federal do Amapá (UNIFAP). Líder do Centro de Estudos de Religião, Religiosidades e Políticas Públicas (CEPRES-UNIFAP). Integra o Grupo de Pesquisa Estudos Interdisciplinares em Cultura e Políticas Públicas e o Observatório da Democracia, Direitos Humanos e Políticas Públicas. E-mail: marcosvinicius5@yahoo.com.br.

${ }^{* * *}$ Licenciado em Sociologia pela Universidade Federal do Amapá (UNIFAP). Integra o Centro de Estudos de Religião, Religiosidades e Politicas Públicas (CEPRES-UNIFAP). E-mail: danilo.deoliveira@hotmail. com
} 
Abstract

This article seeks to present an analysis on the insertion of Rádio São José in the Amapá religious media scene, observing from a historical and conceptual perspective that involves thinking about the religious field in a scenario of religious competition and mediatization. To this end, we present a historical approach that observes communication at the interface with the Catholic Church, highlighting the communicational perspectives that guide the communication protocols of these religious institutions with society. Through the analysis of interviews with actors who are part of Rádio São José and analysis of the programming grid, we indicate the general matrices that guide the media's action in Amapá. As general considerations, we highlight in the role of Rádio São José the predominance of a communication model that favors doing, in the instrumental appropriation of the means of communication in an educational process by transferential media aimed at evangelization of the diffusionist type of church doctrine, which is distant the conceptual, technical and political challenges observed in communication strategies and policies that mark the relationship between the religious field and the media field in a context of competition in the configured religious market.

Keywords: Communication. Religion. Mediatization. Religious Market. Radio São José. Amapá.

\section{Apontamentos teóricos iniciais}

O estudo da inserção do campo midiático deve ser observado, na contemporaneidade, atrelado a um cenário de disputa que caracteriza o mercado religioso (BERGER, 2003). Como dispositivos, as mídias (sobretudo eletrônicas e digitais) estabelecem uma interface complexa com o campo religioso a partir de fenômeno caracterizado pela midiatização (GOMES, 2016). Em linhas gerais, a midiatização se caracteriza como um fenômeno que marca a ação dos campos das mídias na produção da sociabilidade, na particular forma de inserção desses dispositivos na construção de sentidos que organizam a tessitura das relações sociais na contemporaneidade.

A presente pesquisa tem por objetivo fazer uma análise da presença e natureza da atuação da Rádio São José da Diocese de Macapá no cenário midiático do estado do Amapá, considerando a histórica relação entre mídia e campo religioso. O estudo parte da programação da Rádio e, de forma complementar, da realização de entrevista com integrantes da emissora que se dispuseram a atender os pesquisadores.

$\mathrm{Na}$ midiatização, mais do que meios para fazer circular sentidos oriundos de outros campos sociais, as mídias são parte constitutiva dos processos de compreensão elaborados individual e coletivamente (GOMES, 2016), em um movimen-to 
marcado pela produção e circulação de sentidos que se retroalimentam de uma interface de dupla incidência entre os campos midiáticos e demais campos sociais, incluindo o religioso.

O fenômeno da midiatização apresenta-se, do ponto de vista comunicacional, como uma abordagem que insere de modo central o campo midiático em um contexto de concorrência do disputado mercado religioso e nos permite compreender os fenômenos religiosos midiatizados, reconfigurando a prática religiosa no que se refere a modos de fazer, promover e pensar a experiência religiosa.

De acordo com Berger, o mercado religioso é a concorrência entre segmentos religiosos por fiéis, influência da sociedade e disputa política, ideológica e teológica (BERGER, 2003, p. 45). A Igreja Católica não mais detém o monopólio do campo religioso brasileiro, cujo perfil se modificou sensivelmente nas últimas décadas. Mariano (2013, p. 120) salienta que a Igreja Católica vem perdendo fiéis e destaca o crescimento dos evangélicos e dos sem religião. O pluralismo religioso e a competição religiosa são características do campo religioso brasileiro (TEIXEIRA; MENEZES, 2013, p. 23).

Dados do Instituto Brasileiro de Geografia e Estatística (IBGE) apontam a mesma tendência em nível nacional no estado do Amapá a respeito do panorama religioso. Segundo Reis e Carmo (2015), houve aumento substancial dos evangélicos na Amazônia Amapaense. Percebemos a lógica concorrencial imposta pelos pentecostais à Igreja Católica nas últimas décadas (REIS; CARMO, 2015). Entretanto, com o tempo, o mercado religioso recebeu novas instituições, a exemplo do Espiritismo, Adventista, Islamismo, Hinduísmo, religiões ayahuasqueiras, Judaísmo, religiões de matriz africana, ateus, agnósticos, dentre outros atores. Dito de outra forma, o Amapá é caracterizado pela pluralidade e pela competitividade em matéria de religião e religiosidade.

É neste campo em disputa religiosa que a Diocese de Macapá desenvolve estratégias para evitar a estancada da perda de fiéis e da influência da sociedade (CARVALHO; REIS, 2016). O protagonista de reação católica são os padres da Pontifício Instituto das Missões Exteriores (PIME)que, desde 1943, estão à frente da gestão e da evangelização no estado do Amapá ${ }^{1}$ (CARVALHO; REIS, 2016).

De acordo com Oro (1996), a Rádio São José nasce neste contexto de disputa entre as instituições religiosas. Na tentativa de divulgar os ideários católicos, a a- 
genda institucional da Diocese de Macapá serve de espaço para outros organismos católicos divulgarem suas atividades e a programação da Rádio torna-se necessária para que as informações alcancem católicos fervorosos, católicos não praticantes e até mesmo pessoas de outras religiões ou comunidades do interior e das ilhas, que pouco têm acesso a atividades paroquiais ou a padres (REIS; CARMO, 2015).

As atividades da Rádio São José se iniciaram em 2013. A gestão das suas atividades ficou a cargo do padre que é identificado com a espiritualidade do movimento da Renovação Carismática Católica (RCC). Silveira aponta que as rádios de inspiração católica no Brasil ou são gerenciadas pela RCC ou sua programação tem influência deste movimento católico (SILVEIRA, 2014).

Os conteúdos vinculados nos meios de comunicação católicos (sobretudo as rádios) são voltados para músicas religiosas, catequeses, entrevistas, orações e aconselhamentos (CAMURÇA, 2001). A referida proposta de programação é amplamente defendida pelos carismáticos amapaenses. Os programas são essencialmente voltados para espiritualidade, proselitismo e disseminação da doutrina católica (ORO, 1996). Uma das apostas da programação é o espaço para padres cantores ou conhecidos do grande público. De acordo com Souza (2001, p. 34), a popularidade dos sacerdotes é utilizada para angariar audiência e expansão da espiritualidade carismática, uma vez que a maioria destes padres são vinculados à RCC.

Prandi (1997, p. 23) aponta que as rádios católicas controladas pela RCC possuem duas finalidades. A primeira, um movimento "para dentro", o que significa o combate à presença e à influência da Teologia da Libertação nas comunidades católicas. Na Rádio São José, o padre, ao tomar posse, suspendeu as atividades do conselho da Rádio, pois este era composto majoritariamente pelas Pastorais Sociais, Comunidades Eclesiais de Base e outros organismos católicos progressistas. E um segundo movimento, "para fora", que constitui uma reação ao crescimento dos evangélicos. A programação, na qual é proibida a execução de músicas evangélicas, foi pensada para evitar a fuga de fiéis para outras igrejas. Como podemos perceber, a Rádio é assumida institucionalmente pela Diocese de Macapá como uma estratégia na competição entre instituições religiosas.

Sobre as mídias católicas, especificamente, Gomes (2002) pontua a dubiedade como uma característica da relação entre a Igreja e as mídias eletrônicas, considerando a tradição dessa instituição com a imprensa escrita. A ambiência, demandas e configuração do sistema de mídia, com o surgimento do rádio e da televisão 
(final do século XIX e início do século XX), são a origem da dubiedade por desafios envolvendo a apropriação/incorporação dos então novos meios de comunicação à ação pastoral.

Em uma atualização do sistema midiático, em funcionamento sob um novo paradigma de produção e circulação de informação a partir de meios sociotécnicos que marcam a chamada "sociedade em rede" (CASTELLS, 1999), entendemos que essa relação de dubiedade ganha contornos mais complexos e se potencializa quando observamos as instituições religiosas católicas inseridas em um cenário digital de comunicação instantânea.

No tocante ao objeto da análise, que observa a inserção da rádio católica São José no cenário midiático religioso amapaense, o foco da reflexão consiste em observar os meios eletrônicos na relação com a religião, nos termos definidos por Gomes (2002) para avaliar as diretrizes e perspectivas que, historicamente, a Igreja Católica adotou para compreender e orientar o uso das mídias eletrônicas, gerando o que o autor caracteriza como posição dúbia, na medida em que não obedeceram a uma estratégia uniforme em um dado percurso histórico. ${ }^{2}$

A compreensão da Igreja para a comunicação midiática, para Gomes (2002), acabou sobreposta, coexistindo com posições pouco uniformes ao longo dos anos de 1990. Entendemos, no entanto, que a configuração que o autor sistematiza para observar os protocolos e diretrizes de comunicação na Igreja Católica é importante para perceber a ação de algumas emissoras, mesmo em um contexto de demandas para o uso dos meios de comunicação envolvendo a disputa neste mercado e em um contexto de midiatização do campo religioso, protagonizado pelas religiões evangélicas como exemplo mais representativo.

E para entendermos essa compreensão e as sobreposições que subsidiam ou subsidiaram as diretrizes de atuação da Igreja Católica no campo da comunicação eletrônica que marcaram o início da inserção das mídias eletrônicas no contexto católico até os anos de 1990 (com resquícios nos dias atuais), Gomes (2002) apresenta uma configuração interessante para orientar a observação do nosso objeto de análise. De acordo com ele, a dimensão educativa orientou o protocolo comunicativo da Igreja no uso dos meios de comunicação em três tipologias distintas: saber, fazer e pensar. Cabe destacar que cada tipologia incorpora um conceito particular sobre a educação e o papel da comunicação, dos seus usos e apropriações pela sociedade. Resumidamente, conforme o autor, no primeiro caso, a preocupação era 
com o saber, em perspectiva educativa e depositária, preocupada com o conteúdo veiculado e focada na ideia de que os meios eram instrumentos de transferência de conhecimento. A ação da Igreja, nesse caso, era voltada a observar o conteúdo veiculado pelos meios de comunicação e as eventuais interfaces em facilitar ou prejudicar os ensinamentos de uma moral e valores religiosos, focando sua atenção em educar os usuários para lidar com as ameaças da comunicação eletrônica.

No segundo caso, foca-se no processo em que comunicação é um instrumento para educar, na perspectiva da Igreja, pela sua capacidade de gerar efeitos na transmissão de conteúdos de interesse católico e atingir um público amplo, em uma ação behaviorista de mudar atitudes pela presença de mensagens potentes de sentido orientado aos emissores. Nesta vertente, fazer a comunicação capaz de usar o potencial de difusão dos meios para atingir os fiéis marca a relação da Igreja para pensar o uso das mídias.

Já no terceiro caso, observando a importância que não mais o saber e o fazer assumem em um processo educativo, a perspectiva é valorizar o pensar, entendendo a educação como instrumento de promoção da reflexão e o uso dos meios para tal finalidade deve assumir a proposta de promover o pensamento indagador, o que presume uma mudança crítica na relação entre Igreja e fiéis. Nesse caso, o que vale é a perspectiva dialógica para construir uma comunicação com a comunidade, favorecendo processos participativos que garantam o envolvimento comunitário na produção da comunicação religiosa.

Ao observar essas perspectivas sobre comunicação eletrônica, atrelando os meios ao processo educativo, a década de 1990 foi, para Gomes, o período em que essas fases conviveram, sobrepondo-se uma à outra, predominando a "primeira postura, mais preocupada em doutrinar" (Gomes, 2002, p. 341). No início dos anos 2000, o autor já chamava a atenção para o fenômeno da midiatização do campo religioso e as novas formas de inserção/ apropriação da religião nessa esfera, abordando o desafio de pensar a evangelização considerando as restrições, especificidades e modos de produzir e circular sentidos em um dispositivo midiático.

\section{Comunicação na Igreja Católica no Amapá: O caso da Rádio São José}

A preocupação com a presença da Igreja Católica nos meios de comunicação de forma oficial foi apontada pelo Concílio Vaticano II (1962-1965). As decisões tomadas aí tinham por objetivo que as comunidades católicas modernizassem sua 
forma de comunicar e dialogassem mais com as questões contemporâneas. Foi incentivado que os organismos católicos investissem em programas em rádio, jornal ou televisão. A ideia era expandir o ideário católico por meios das mídias e atingir um público maior. Isto é, documentos como o "Communio et progressio", publicado em 23 de maio de 1971 pelo papa Paulo VI, que finalizou o Concílio Vaticano II, em 1965, ${ }^{3}$ mostram a manifestação da Igreja Católica afim de se apropriar desse meio para propagar sua visão de mundo e se incluir na sociedade que se modernizava. No documento, o papa destaca a importância do papel social nos meios de comunicação.

A seguir, os principais documentos da Igreja que posicionam a necessidade das expressões católicas utilizarem os meios de comunicação (sobretudo o rádio) para disseminação de suas atividades e posicionamentos em relação aos problemas politicos, econômicos, sociais e espirituais:

$>$ Instituição da celebração para o Dia Mundial das Comunicações Sociais 1967;

$>$ Communio et progressio - 1971;

$>$ Documento de Puebla - 1979;

$>$ Evangelii Nuntiandi-1975;

$>$ Encíclica Redemptoris Missio - 1990;

$>$ A 26 Campanha da Fraternidade teve como tema "Fraternidade e Comunicação", buscando despertar a consciência crítica do receptor no uso da mídia, como atitude interior necessária para a comunicação da verdade e da paz-1989.

A partir dos anos de 1990, os organismos católicos aumentam o seu rol de obtenção de concessão de rádio e televisão ou de compra de espaços em emissoras não religiosas para apresentação de seus programas, missas, terços ou outros momentos oracionais. A ideia de Igreja Eletrônica é pensada neste contexto. A Igreja Católica opta pelo uso dos meios eletrônicos - nesse período, rádio e televisão - para inserção de seus interesses institucionais. Tanto o rádio quanto a televisão passam a ser instrumentos de promoção do conteúdo católico, de posicionamentos políticos e sociais da Igreja, assim como uma forma para que diretrizes pensadas pelos organismos católicos possam atingir públicos que por alguma razão possuem dificuldades de ir até as paróquias (ASSMANN, 1986). 
Camurça (2009) reforça a ideia que as rádios que surgem a partir das décadas de 1990, vinculadas e administradas por setores da Igreja Católica, optam por uma linguagem simples, objetiva, uma programação musical, oracional, transmissão de missas e outros eventos católicos, programas de entrevistas sobre conteúdo doutrinal católico e interação ao vivo com os ouvintes. Isto é, uma tentativa de pensar uma estratégia radiofônica que consiga despertar o interesse no público em acompanhar a programação das rádios católicas.

A proposta de analisar a inserção da Rádio São José no cenário midiático religioso amapaense observando a emissora sob uma perspectiva histórica e comunicacional considerou, para efeitos metodológicos, a pesquisa documental e de campo (com entrevistas à equipe que presentemente atua na Rádio) como instrumentos de coleta de dados.

Com relação à análise, procuramos avaliar, em uma primeira dimensão histórico-institucional, a constituição e o funcionamento da emissora. Articulada a essa perspectiva, tratamos de um segundo aspecto de análise, o conceitual, observando - a partir dos processos de produção dos conteúdos veiculados - as características, marcas e vestígios das perspectivas e diretrizes de comunicação deliberadas pela Igreja Católica, bem como as tipologias que orientam o protocolo comunicativo entre igreja e os meios de comunicação, definidos por Gomes (2002), ensaiando apontamentos para dimensionar a inserção da emissora no contexto da midiatização e da concorrência do mercado religioso.

Antes de esboçarmos o quadro de análise, é importante uma breve contextualização sobre a constituição do campo midiático religioso católico no Amapá. O instrumento de comunicação da Igreja, de 1959 até 1974, foi o jornal impresso A Voz Católica, editado pelo padre Jorge Basile e o cônego Ápio Campos. O jornal, que circulava aos domingos, teve um total de 15 volumes, 662 números e 2.659 folhas (PIMENTEL, 2015).

A primeira experiência de comunicação em mídia sonora do Amapá foi em 1961, com a entrada da emissora Rádio Equatorial (ZYD-11, ondas médias, 1.490 $\mathrm{kHz}$ ), pertencente à Sociedade Anônima Rádio Técnica do Amapá (SATRA) (CUNHA; FREIRE, 2007, p. 5). Em 1964, a emissora foi fechada. A prelazia de Macapá concedeu outorga de rádio AM, o que tornou possivel inaugurar, em 1968, a Rádio Educadora São José LTDA., operando em ZYA-52, 1.460 kHz - ondas médias; e 2.400 
$\mathrm{kHz}$ - ondas tropicais, regulamentada pelo Decreto $\mathrm{n}^{\circ} 58.544$, de 30 de maio de 1966, e pelo Decreto $n^{\circ}$ 53.938, de 2 de agosto de 1966.

Cunha e Freire (2007) afirmam que o projeto de comunicação da Igreja Católica no então Território Federal objetivava criar uma emissora de rádio alternativa. Em Macapá existia apenas a Rádio Difusora, emissora oficial do governo do território. A Rádio Educadora São José, então, assumiu um papel de destaque e de grande expressão de audiência.

A emissora católica tinha o caráter religioso em seus princípios basilares, mas não definiu toda a sua grade, que contava com uma programação variada, desde radioteatro, passando por noticiário, esporte e programas de auditório e crônicas, com conteúdo exclusivamente voltado para o catolicismo.

Durante a Ditadura Militar, a linha editorial da Rádio seguiu para o lado mais politizado, assumindo um viés progressista em um momento de fortalecimento da Teologia da Libertação, traduzindo-se em uma posição crítica local em relação ao governo. A Rádio Educadora permaneceu no ar por mais de uma década, encerrando em 1978 as suas atividades. Nesse mesmo período, o jornal A Voz Católica também foi fechado. No final dos anos de 1970 até a década de 1980, a Rádio Difusora de Macapá assumiu o papel de divulgação dos informativos da Igreja Católica local. Semanalmente eram transmitidas missas, terços, catequese do bispo ou de padres e festas católicas, a exemplo da Festa de São José - padroeiro da Diocese de Macapá - e do Círio de Nazaré. A Rádio Difusora divulgava o posicionamento oficial da Igreja em relação a temas da sociedade local.

Cunha e Freire (2007) apontam que as causas do fechamento da Rádio Educadora foram políticas, em função dos embates com os censores do governo militar, e financeiras. Lideranças católicas que trabalhavam na Rádio Educadora neste período afirmam que o motivo tenha sido apenas de ordem financeira. Sem ter uma emissora de rádio própria, a Igreja procurou introduzir programas em outros canais, como na emissora vinculada ao governo do território, a Rádio Difusora - o programa "A Prece da Ave Maria", produzido pela Pastoral da Comunicação, no ar até os dias de hoje.

Em 1998, chegou a Macapá como repetidora a Rede Vida de Televisão. Já em 2004, passou a funcionar, também como repetidora, a TV Nazaré. Apesar de ser uma programação nacional, a Rede Vida foca na propagação de evangelização nos 
valores morais e éticos de famílias; a TV Nazaré tem uma proposta de evangelização mais regionalizada, voltada à Amazônia Legal.

Neste contexto de ampliação dos canais católicos, no final dos anos de 1990 e o início dos anos 2000, o então bispo, Dom João Risatti, começou a planejar o projeto para a aquisição da concessão educativa de uma rádio, seguindo uma linha pastoral mas operando na mesma proporção que a antiga Rádio Educadora. Em 2003, Dom João faleceu na Itália, local onde nasceu. O projeto técnico da Rádio já estava caminhando para entrar em trâmite legal. Em 2005, Dom Pedro José Conti, bispo da Diocese de Santíssima Conceição do Araguaia, assumiu a Diocese de Macapá e, entre tantos desafios, deu continuidade ao projeto de seu antecessor, alimentado pelos leigos da diocese.

A Rádio São José FM 100.5 começou a funcionar em 7 de abril de 2013, sendo caracterizada no seu estatuto como uma emissora sem fins lucrativos mantida pela Fundação Educadora São José, dirigida pelo clero. Sua frequência alcança 8 municípios e parte da mesorregião do Marajó (Afuá, Breves, Chaves e Gurupá), no estado do Pará. A outorga de Serviço de Radiodifusão Sonora está na categoria educativa.

A Rádio São José está filiada à Rede Milícia SAT e retransmite a produção jornalística da Rede Católica de Rádio (RCR) e da Rede Notícia da Amazônia (RNA). A estrutura administrativa da Rádio é composta por seis pessoas e dividida entre a direção, três operadores de áudio, uma auxiliar de serviços gerais e uma secretária. A direção-geral da emissora é de responsabilidade do sacerdote Fábio Rogério Pereira Bezerra, adepto da espiritualidade carismática e membro da Comunidade Católica Carismática Shalom. O público-alvo são ribeirinhos que moram nas ilhas do $\mathrm{Pa}-$ rá, na região do Marajó e nas comunidades distantes as quais a Igreja Católica tem dificuldades de acessar devido à escassez de padres. A Rádio São José é mantida financeiramente por doações de fiéis, inserções comerciais, rifas, bingos e por investimentos da cúria da Diocese de Macapá. Na nossa pesquisa não identificamos a compra de horários por parte de nenhum organismo católica ou organismos não católicos. As inserções oracionais do bispo e dos padres presentes na programação da Rádio são iniciativas da direção que assumem os custos da execução destes programas.Ao longo da programação semanal, as atividades paroquiais e diocesanas são divulgadas.

\section{Sobre a Programação da Rádio São José FM de Macapá}


O quadro a seguir mostra como está organizada a grade de programação da Rádio São José FM e foi elaborado com base em informações do site da Rádio e do encarte de 2019 do seu programa A Hora Santa, bem como pelo acompanhamento da programação.

Para fins de organização da natureza dos conteúdos veiculados, enquadraremos os programas listados na grade de programação da emissora em três gêneros: entretenimento; jornalístico; e confessional. No primeiro gênero estão os programas de músicas ou conteúdos que retratam o mundo da cultura da religião católica (seus atores, eventos, produtos e processos tradicionais que caracterizam essa prática religiosa). No gênero jornalístico estão os programas onde predominam a proposta de divulgar informação factual e de interesse público ligada à sociedade em geral, como também aqueles com função informativa orientada a agendar e destacar ações institucionais da Igreja. No terceiro gênero, confessional, estão as programações com foco na evangelização e difusão de conhecimentos e ensinamentos religiosos, marcadas por valores e perspectiva católicos. É importante destacar que alguns gêneros se entrecruzam na proposta de alguns programas (conforme quadro).

Observando a programação, o que se destaca é que a emissora tem concessão para operar como rádio educativa, o que a insere em um contexto particular no que se refere à sustentabilidade financeira e aos compromissos com a produção de conteúdo na comparação com rádios comerciais ou comunitárias - outras duas modalidades de outorga prevista no marco legal brasileiro. Na programação da Rádio, temos a presença institucional de programas e informações da Diocese de Macapá, programas ligados a grupos carismáticos: RCC, Comunidade Shalom e os programas musicais. Há também programas vinculados à Pastoral Familiar, grupos da Juventude Católica, Pastoral Vocacional, Pastoral Catequética e da Pastoral da Liturgia.

De acordo com Lopes (2011), a regulamentação da radiodifusão educativa está compreendida no Decreto-Lei no 236/1967; no Decreto nº 2.108/1996; e na Portaria Interministerial $n^{\circ} 651 / 1999$. O foco dessa modalidade de radiodifusão não é o lucro, como as emissoras comerciais; ao contrário, deve veicular programas educativo-culturais e atividades de natureza educacional, cultural, pedagógica e de orientação profissional (LOPES, 2011, p. 8). A essas emissoras está permitido o uso por sistemas de ensino como instrumento de apoio à formação básica, superior e 
profissional, o que vincula a sua maioria a instituições e/ou fundações com atuação e vínculo com a educação.

A sustentabilidade de uma emissora educativa está na possibilidade de financiamento pela Lei Rouanet (Lei $n^{\circ} 8.313 / 1991$ ) e pela Lei $n^{\circ} 9.637 / 1998$, especificamente seu artigo 19, regulamentado pelo Decreto $\mathrm{n}^{\circ} 5.396 / 2005$, que permite a publicidade institucional de entidades de direito público e privado, que não pode ser confundida com comercial nos intervalos, como é comum em rádios comerciais, mas atender ao princípio educativo-cultural próprio das emissoras educativas (LOPES, 2011; LOPES, 2015).

O foco educativo-cultural marca a programação em uma emissora educativa, sendo a característica que obrigatoriamente deve constar inclusive em outros conteúdos divulgados (esportivo, entretenimento, informativo). Nesse aspecto, percebemos que a Rádio São José atua com uma agenda educativa que observa a religião como fenômeno cultural, e a ação comunicativa do veículo é atuar sob a perspectiva educativa na transferência de conhecimentos $\mathrm{e}$ saberes acumulados $\mathrm{e}$ (re)produzidos na apropriação da cultura católica por agentes inseridos na religião. Em linhas gerais, exercitam a evangelização acionando elementos da cultura católica em programas formatados para o entretenimento, para a difusão de informação jornalística e nos próprios programas confessionais, elaborados na perspectiva discursiva nos moldes estéticos (do ponto de vista da linguagem e formato) sob a lógica do espaço religioso tradicional (a Igreja).

Neste último caso, o protocolo de comunicação adotado no processo de evangelização acontece, sobremaneira, através da mídia (GOMES, 2002), na transposição de discursos, práticas e protocolos de comunicação constituídos por atores e na lógica do espaço institucional tradicional - a Igreja e seus respectivos circuitos sociais. Essa perspectiva segue com restrições uma ação no campo da comunicação distante da ação evangelizadora que não se dá pela e através, mas nas mídias (GOMES, 2002).

Essa ação evangelizadora nas mídias, exigindo recursos, linguagens e formatos mais específicos, é uma tendência hegemônica de comunicação midiática religiosa com pioneirismo das igrejas pentecostais que, observada na perspectiva da midiatização, instaura um processo que marca a utilização pelo campo religioso do campo midiático como instância de realização e atualização da questão da fé (Gomes, 2002, p. 343). 
Nesse processo, na lógica de produção e circulação de sentidos própria dos espaços midiáticos, a religião ressignifica o processo de oferta do serviço religioso , incorporada sob o paradigma de fiel que é massivo e homogêneo, que se articula a partir dos dispositivos midiáticos (com estética, linguagem e narrativa próprios), promovendo o consumo da experiência religiosa pautada em componentes discursivos emocionais, com pouca ou quase nenhuma participação no processo de comunhão e interação necessários à vivência religiosa espetacularizada (GOMES; FAUSTO NETO, 2005).

Na Rádio São José, a perspectiva da Igreja orienta a abordagem editorial para o agendamento e enquadramento dos temas e questões do campo da cultura e do campo jornalístico, em uma tentativa de educação (religiosa) pela mídia (GOMES, 2002), o que indica uma tradição predominante da comunicação eletrônica católica na evangelização do tipo difusionista da doutrina da Igreja sob uma perspectiva do fazer, compreendendo o potencial educativo da mídia radiofônica como instrumento que não pode ser evitado ou condenado, mas potencializado pela capacidade de difusão de um conhecimento produzido pelo campo religioso católico, conforme indicações de Gomes e Fausto Neto (2005).

Em entrevista, a direção da emissora afirmou que o perfil de atuação da Rádio acompanha o da Igreja Católica. Os estilos musicais tocados, a difusão de cultura com a veiculação de repertório musical vai além do gênero católico e da música popular - neste último caso, desde que não atentem para valores da religião, como apologia a aborto, morte, violência, entre outros.

A programação jornalística, como um eixo de conteúdos importantes e obrigatórios na programação de um veículo de natureza educativa, é predominantemente retransmitida por emissoras organizadas em redes: a Rede de Notícias da Amazônia (RNA) e a Rede Católica de Rádio. Sobre a programação, destacamos a produção informativa factual e voltada à prestação de serviços; o jornalismo se torna, assim, um instrumento para difundir informação sobre a atualidade sob o enquadramento da Igreja.

A RNA, que pensa a comunicação privilegiando a Amazônia, é constituída por 12 emissoras de rádio na região, com postura editorial atrelada à formação da consciência crítica, com proposta voltada a democratizar a comunicação considerando as especificidades da Amazônia. A Rádio São José não integra a rede, mas retransmite o conteúdo jornalístico produzido pelas emissoras integradas. 
O conteúdo jornalístico retransmitido da RNA, para além de ser institucional, que informa sobre a ação da Igreja (como é o conteúdo jornalístico predominante produzido pela Rádio São José), adota postura crítica. Segundo Silva, na constituição da RNA, os bispos responsáveis pelas emissoras integrantes foram informados de que esta seria uma rede amazônica, e não católica, sendo "as emissoras convidadas ligadas às dioceses e prelazias por serem mais independentes do poder político e econômico" (SILVA, 2016, p. 57).

O conteúdo jornalístico retransmitido da RNA pela Rádio São José como parte de sua programação jornalística - Caminhos da Amazônia e Jornal Notícias da Amazônia - assume uma vertente crítica que destoa da produção jornalística local, pouco atrelada a observar o cotidiano e a agenda pública regional em um processo de enquadramento sob a ótica da Igreja, assumindo uma postura jornalística para divulgar as ações da instituição. Essa postura renuncia a outra estratégia de inserção do campo religioso quando pensada sua intersecção com as mídias: a inserção e disputa junto à opinião pública em torno de enquadramentos e sentidos construídos pelo discurso jornalístico demarcadamente significado pela perspectiva religiosa (como são emissoras comerciais geridas por grupos ou instituições religiosas pentecostais que imprimem na cobertura jornalística a narrativa definida por uma linha editorial aliada a estratégias e interesses das instituições religiosas que as controlam indiretamente).

O radialista, apresentador e operador de áudio da emissora, Fábio Tomaz, afirmou que a direção da Rádio orienta os locutores a não tomarem partido (no que se refere à preferência político-partidária). A recomendação é de que, quando forem citar algum problema político-social, que se fale no plural - "os políticos" - para não citar nomes e para que não comprometa a Rádio e a fundação educadora São José.

\section{Rádio, Igreja e Concorrência Religiosa}

Nesse aspecto, destacamos a relação da mídia religiosa com a Igreja em um contexto de concorrência neste mercado que tem no campo midiático dispositivo para operar essa disputa. De imediato, é importante ressaltar que a inserção da Rádio São José no cenário midiático religioso do Amapá como canal educativo caracteriza-se, conforme exposto no item anterior, em uma ação comunicacional predominante da Igreja Católica na relação com os meios eletrônicos: a observância ao papel educativo dos meios para expandir os valores e ensinamentos católicos em 
uma prática de evangelização através da mídia, focando a atenção nos aspectos produtivos (fazer) que envolve a comunicação.

Isso significa que a evangelização na mídia, que presume considerar a expertise e a especificidade de pensar a ambiência midiática para dela se apropriar estrategicamente para a oferta religiosa em um contexto de concorrência, está muito aquém do que é a produção de conteúdos e estratégias editoriais da Rádio. Para além dos conteúdos produzidos e registrados no mapa de programação evidenciarem essa caracterização geral que marca a inserção da emissora no campo midiático religioso local, essas considerações se amparam na configuração institucional que sustenta as estratégias e decisões editoriais. Isso nos leva a observar a relação da Rádio São José com a instituição religiosa, observando como se inter-relacionam na construção de uma esfera pública midiática católica no âmbito local.

O corpo técnico é reduzido. Os locutores são leigos voluntários participantes de pastorais e movimentos que passam por formação realizada pela Rádio sobre técnicas de locução, de programações e como produzir um programa. A avaliação da programação é feita pela direção da Rádio junto com os funcionários, principalmente com os operadores de áudio. Permanecem no ar os programas que estão, na avaliação do diretor, de fato respondendo à necessidade da emissora e alguns outros saíram do ar pela falta de audiência. A maioria dos leigos voluntários que está colaborando com a programação da Rádio são envolvidos em realidades sociais da diocese, mas não fazem parte das pastorais sociais.

A emissora mantém um processo decisório centralizado, sem a participação de agentes vinculados a pastorais sociais ou de grupos e movimentos internos que compõem a Igreja Católica. Há dificuldades para articular estratégias com as pastorais sociais para ocupação do espaço da Rádio, especialmente com a Pastoral da Comunicação (Pascom). A decisão da centralização deu-se em função de manter o caráter proselitista e confessional da Rádio São José por parte da direção da emissora. Havia um entendimento que a programação deveria ser totalmente de conteúdo católico, evitando-se programas, músicas e diálogos de outros credos religiosos, músicas secularizadas ou assuntos que não fossem de interesse institucional de grupos conservadores ligados à diocese de Macapá.

Houve uma tentativa frustrada de abrir espaço para a Pascom na grade de programação. Logo no início das atividades da emissora, a pastoral teve papel importante na formação de locutores e na sugestão dos programas que ainda hoje es- 
tão no ar. Essa vertente aproximou-se do paradigma de ação comunicacional da Igreja centrado na promoção do saber, conforme indicado por Gomes (2002), valorizando um fazer comunicacional-educativo problematizador e crítico.

Para o jornalista Oscar Filho, a linha editorial dos anos de 1960 era mais educativa, mais proativa, mais preocupada com a qualidade, a informação, a opinião e a conscientização. A Rádio São José FM de Macapá não tem nada da Rádio Educadora São José AM; é outra emissora, é outra concessão, é outra sintonia:

Como nós tivemos que colocar a Rádio São José 100.5 no ar logo depois da concessão, assumiu incialmente a direção o padre Lourenço, que depois se afastou, ele estava fazendo um curso de comunicação nas Paulinas, um jovem sacerdote, acho que até para vencer um pouco a timidez. O padre Lourenço me surpreendeu muito, ele era muito participativo, envolvia todo mundo na discussão. Hoje mais da metade da programação que está na São José FM no ar foi sugestão da Pascom, nome de programas, estruturas, propostas, ele pedia sugestão e cobrava, "estou precisando de uma ideia assim, mandem projetos para cá, vamos discutir, vamos sentar", e essa coisa toda. E aí a gente foi organizando a programação da Rádio São José. Os meninos que estão hoje aí apresentando programa, o Angley, a Vovó Zete, sei lá, tantos outros lá, Angleson... A gente estava apresentando o programa "Fé na Vida", e eles sentavam lá, na parede do estúdio, ficavam olhando para aprender, que também a Pascom fez oficina né? São pessoas mais jovens, mais interessadas em contribuir com a Rádio, teve um grupo de formação, uma ideia só? Também ajudou um pouquinho, era o que Dom Pedro pedia pra gente. Pela visão de Dom Pedro... ele chegou a pensar em a Rádio ser dirigida por leigos com a permissão do sacerdote mais a comunidade. Mas o clero vetou. ${ }^{4}$

Sobre a relação da emissora com os grupos internos da Igreja, como Comunidades Eclesiais de Base (CEBs), ${ }^{5}$ e com os Organismos Católicos de inspiração carismática - RCC, Comunidade Católica Shalom ${ }^{6}$ e Amigos da Canção Nova ${ }^{7}$-, o que se observa é a inserção restrita desses grupos no conjunto da programação da emissora, sem a participação nas decisões editorais e gestão participativa da emissora. A Renovação Carismática Católica só tem espaço no programa "Cura-me Senhor", às segundas-feiras, mas não atua nas decisões da emissora. Já a com relação às CEBs, a inserção na grade é com o programa "Círculo Bíblico no Rádio" (originalmente um quadro do programa "Fé na Vida"). O entendimento é que setores mais progressistas da Igreja Católica não estão de acordo com a linha editorial proposta pela direção da Rádio. Tais setores, que propõem uma programação voltada para abordagens das questões sociais e politicas do estado do Amapá, são contrá- 
rios a uma visão mais confessional e proselitista e favoráveis a um diálogo maior com outros credos religiosos a partir da programação da Rádio.

\section{Considerações finais}

A inserção da Rádio São José no cenário midiático religioso do Amapá está distante dos desafios concernentes à comunicação midiática religiosa em tempos de midiatização (como marco conceitual para pensar mídia e religião) e de concorrência religiosa (como contexto para observar a ação institucional das igrejas no campo religioso) na contemporaneidade.

Os protocolos e estratégias de comunicação da Rádio estão calcadas, predominantemente, em uma agenda para a comunicação que observa a dimensão do fazer em uma proposta de evangelização através dos meios, deslocada de uma abordagem editorial ligada ao saber, em uma perspectiva educativa crítica tanto para o uso como para subsidiar diretrizes da comunicação, quando produzida pela Igreja. Ainda mais distante está de um protocolo de comunicação capaz de orientar a ação midiática mediada por uma postura que privilegie o pensar como diretriz para observar os processos comunicacionais e concebê-los quando produzidos pela Igreja, o que presume uma agenda mais participativa e integrada ao espaço não exclusivamente institucional da instituição religiosa, e sim da comunidade católica como um todo. Em nosso entendimento, essa constatação resulta da pouca capacidade de inclusão de outros atores no espaço decisório que define a perspectiva editorial da emissora, capaz de incorporar outros discursos e percepções que não se restrinjam à institucionalidade da Igreja.

Os discursos reiterados coletados na pesquisa de campo destacam a neutralidade, o não envolvimento político, a predominância de uma responsabilidade com uma agenda endógena (da instituição), a evangelização centrada na difusão da doutrina católica e enfatizada por um fazer que aproveita o canal midiático para falar a um público que a Igreja acredita atingir pelo potencial de difusão do veículo. Essa configuração revela o estágio de inserção que se mostra predominante ainda na comunicação católica na contemporaneidade. Esse cenário local reflete a falta de uma política de comunicação estratégica da Igreja Católica, permeada pela instabilidade e contradição identificada por Gomes (2002) ao observar a produção dos documentos sobre comunicação pela Igreja na década de 1990. A falta de atualização das 
ações e estratégias de comunicação diante dos desafios que envolvem a ação da Igreja, que passam obrigatoriamente pela sua inserção no campo midiático contemporâneo são, em resumo, o diagnóstico para atuação da Rádio São José no âmbito local.

A própria programação revela uma fragilidade da emissora, como rádio educativa, de imprimir à produção local uma identidade que não se restrinja ao foco comum da ação comunicativa da Rádio, que é a prática predominante da evangelização eletrônica através do rádio sob ritos, discursos e linguagens que desconsideram o próprio papel da comunicação eletrônica em um contexto informacional. Cenário marcado pela organização dos dispositivos tecnológicos sob a lógica em rede e de apropriação do campo midiático pelo religioso, sob termos, estratégias e processos específicos orientados pelos próprios dispositivos midiáticos situados em um cenário concorrencial que não prescinde da ação dos meios de comunicação.

Somado a isso, a inserção da Rádio São José no campo midiático religioso local conta com uma frágil estrutura profissional, com forte presença de voluntários, por uma estratégia editorial que não incorpora no processo decisório e produtivo de conteúdos a diversidade e o conjunto das potencialidades em saber, fazer e pensar a religião que permeia a própria Igreja. Somada a isso está a vigência de uma prática comunicacional que pensa a comunicação católica de forma institucional, dependente da estrutura de poder da Igreja, até mesmo quando a instituição não exerce diretamente controle do veículo midiático.

\section{Referências:}

ASSMANN, Hugo. A igreja eletrônica e seu impacto na América Latina. Petrópolis: Vozes, 1986.

BERGER, Peter. O dossel sagrado: Elementos para uma teoria sociológica da religião. São Paulo: Paulus, 2003.

CAMURÇA, Marcelo. Renovação Carismática Católica: entre tradição e modernidade. Rhema. Juiz de Fora: CES, v. 7, n. 25, 2001. pp. 169-186

CARVALHO, Joel Pacheco; REIS, Marcos Vinicius de Freitas. A Igreja Católica na Amazônia: diversidade religiosa e intolerância.O Observatório da Religião. Belém: UEPA,v. 3, n. 1, 2016.pp. 157-172.

CASTELlS, Manoel. A sociedade em rede. São Paulo: Paz e Terra, 1999.

CUNHA, Rodrigo do Espírito Santo; FREIRE, Milena Carvalho Bezerra. Rádio Educadora São José: O recurso rádio fônico na comunicação católica durante os Anos 
de Chumbo no Amapá, 2007. Disponível em: www.ufrgs.br/alcar/encontrosnacionais- $1 / 5^{\circ}$-encontro- 2007 -

1/Radio\%20Educadora\%20Sao\%20jose\%20\%20recurso\%20radiofonico\%20na.pdf. Acesso em 20 de maio de 2018.

GOMES, Pedro Gilberto. Decifra-me ou te devoro... Sobre a evangelização e a mídia do ponto de vista da comunicação. Perspectiva Teológica. Belo Horizonte: FAJE, v.34, 2002. pp. 335-350.

LOPES, Ivonete da Silva. Televisão pública e modelos de financiamento: análise do caso brasileiro. Eptic On-Line.Aracajú: UFS, v. 17, n.1, 2015. , pp. 33-48.

LOPES, Cristiano Aguiar. Regulação da radiodifusão educativa (Estudo). Brasília: Câmara dos Deputados, 2011.

PIMENTEL, Walbi Silva. A igreja dos pobres: Origem e desenvolvimento das CEBs no Amapá (1966-1983). Monografia (Especialização em História e Historiografia da Amazônia). Macapá: Universidade Federal do Amapá, 2015.

PROGRAMA A HORA SANTA 24 ANOS (encarte). A Conquista 6 anos em sintonia com a sua fé. Macapá: Arquiplan Projetos, 2019.

REIS, Marcos Vinicius de Freitas; CARMO, Arielson Teixeira. O Campo Religioso Amapaense: Uma análise a partir do Censo do IBGE de 2000 e 2010. Revista Observatório da Religião. Belém: UEPA, v. 2, n. 2, 2015. pp. 176-197.

SILVA, Antonia Costa da. Belo Monte: Vozes que clamam o jornalismo ambiental e a Rede de Notícias da Amazônia. Boa Vista: Editora da UFRR, 2016.

SILVEIRA, Emerson. José. Catolicismo, midia e consumo: Experiências e reflexões. São Paulo: Fonte Editorial, 2014.

TEIXEIRA, Faustino. MENEZES, Renata. Religiões em movimento:O Censo de 2010. Petrópolis: Vozes, 2013.

1Os missionários do PIME também destacaram-se pela presença no interior do estado do Amazonas, no município de Parintins. Há padres do PIME também nos estados de São Paulo, Paraná, Pará e em algumas regiões do nordeste brasileiro.

${ }^{2} \mathrm{~A}$ orientação dos documentos oficiais da Igreja Católica é de que as rádios tenham programação de acordo com os valores católicos, sejam espaços de divulgação das atividades paroquiais e diocesanas e tenham por objetivo a atração de novos fiéis ou a manutenção dos que já dizem católicos.

3O Concílio Vaticano II foi iniciado em 1962 e concluído em 1965.

4Entrevista realizada com o jornalista Oscar Filho, no dia 4 de janeiro de 2020, nas dependências do Centro Diocesano de Macapá.

${ }^{5}$ As Comunidades Eclesiais de Bases são grupos de fiéis católicos organizados em comunidades que promovem diálogos e participação nos movimentos populares em defesa da vida e participam das discussões políticas e sociais. Teve início entre as décadas de 1970 e 1980, influenciado pela Teologia da Libertação.

${ }^{6}$ A Comunidade Católica Shalom, com presença em vários países, foi fundada em 1982, na cidade de Fortaleza, estado do Ceará. Os fundadores são Moyses Filho e Emir Nogueira. No Amapá, está presente desde os anos de 1990. As atividades desenvolvidas são projetos sociais, formações, retiros espirituais e missas 
7A Comunidade Canção Nova foi fundada em 1979 pelo Pe. Jonas Abib, na cidade de Cachoeira Paulista, interior do estado de São Paulo. Com presença em vários países, no Amapá as atividades são desenvolvidas desde os anos 2000 .

Recebido em 25/09/2020

Aceito para publicação em 26/03/2021 
Anexo I:Tabela de Programação Rádio São José FM de Macapá

\begin{tabular}{|c|c|c|c|c|c|}
\hline Programa & Apresentador & Dia da semana & Horário & Objetivo & Gênero \\
\hline Despertar da Fé & $\begin{array}{l}\text { Elielson Lacerda (Mo- } \\
\text { vimento Eucarístico } \\
\text { Jovem) e convidados }\end{array}$ & $\begin{array}{l}\text { Segunda a sex- } \\
\text { ta-feira }\end{array}$ & $6 h-7 h$ & $\begin{array}{l}\text { Incentivar os ouvintes a criarem o hábito de fazer } \\
\text { oração pela manhã, ler o evangelho do dia e refletir } \\
\text { sobre a palavra diária. }\end{array}$ & Confessional \\
\hline $\begin{array}{l}\text { Jornal Brasil } \\
\text { Hoje }\end{array}$ & $\begin{array}{l}\text { Produzido pela Rede } \\
\text { Católica de Rádio }\end{array}$ & $\begin{array}{l}\text { Segunda a sex- } \\
\text { ta-feira }\end{array}$ & $7 \mathrm{~h}-8 \mathrm{~h}$ & $\begin{array}{l}\text { Levar ao ar um jornal produzido por emissoras que } \\
\text { trabalhem de forma conotativa mantendo a mensa- } \\
\text { gem do evangelho e a responsabilidade jornalistica, } \\
\text { bem como difundir informações da Igreja Católica } \\
\text { no Brasil. }\end{array}$ & Jornalístico \\
\hline $\begin{array}{l}\text { Jornal Amapá } \\
\text { Hoje }\end{array}$ & $\begin{array}{l}\text { Atualmente sem apre- } \\
\text { sentador e sem pro- } \\
\text { dução }\end{array}$ & $\begin{array}{l}\text { Segunda a sex- } \\
\text { ta-feira }\end{array}$ & $\begin{array}{l}\text { Atualmente } \\
\text { fora do ar }\end{array}$ & $\begin{array}{l}\text { Levar ao ar um jornal com responsabilidade jorna- } \\
\text { lística mantendo a mensagem do evangelho e infor- } \\
\text { mando sobre a ação da Igreja Católica no Brasil. }\end{array}$ & Jornalistico \\
\hline $\begin{array}{l}\text { Clube do Ouvin- } \\
\text { te }\end{array}$ & $\begin{array}{l}\text { Zeth Carvalho } \\
\text { (Membro da Liturgia } \\
\text { da Diocese de Maca- } \\
\text { pá) }\end{array}$ & $\begin{array}{l}\text { Segunda a sex- } \\
\text { ta-feira }\end{array}$ & $8 h 30-10 h$ & $\begin{array}{l}\text { Interação com o ouvinte, pedido musical católico e } \\
\text { informações sobre as atividades realizadas nas igre- } \\
\text { jas da cidade e do interior. }\end{array}$ & Entretenimento \\
\hline $\begin{array}{l}\text { De Bem com a } \\
\text { Vida }\end{array}$ & $\begin{array}{l}\text { Angley Pantoja (Ju- } \\
\text { ventude Missionária) }\end{array}$ & $\begin{array}{l}\text { Segunda a sex- } \\
\text { ta-feira }\end{array}$ & $10 h-12 h$ & $\begin{array}{l}\text { Levar entretenimento, participação do ouvinte, in- } \\
\text { formações sobre eventos locais e dicas de saúde, } \\
\text { esporte, lazer, direitos, meio ambiente etc. }\end{array}$ & Entretenimento \\
\hline Santo do Dia & Padre Gerso Lucio & $\begin{array}{l}\text { Segunda a sex- } \\
\text { ta-feira }\end{array}$ & $\begin{array}{l}6 \mathrm{~h} ; 12 \mathrm{~h} ; 17 \mathrm{~h} \mathrm{e} \\
23 \mathrm{~h}\end{array}$ & $\begin{array}{l}\text { Apresentar a história e testemunho de vida do santo } \\
\text { ao qual a Igreja faz memória naquele dia. }\end{array}$ & Confessional \\
\hline Palavra do Bispo & Dom Pedro José Cont & $\begin{array}{l}\text { Segunda a sex- } \\
\text { ta-feira }\end{array}$ & $\begin{array}{l}6 \mathrm{~h} ; 12 \mathrm{~h} ; 17 \mathrm{~h} \mathrm{e} \\
23 \mathrm{~h}\end{array}$ & $\begin{array}{l}\text { Levar aos ouvintes reflexões da vida cristã, explica- } \\
\text { ções sobre o cotidiano da vida em Igreja, bem como } \\
\text { aproximar o bispo do ouvinte católico, em especial } \\
\text { os ouvintes das ilhas. }\end{array}$ & Confessional \\
\hline Fé na Vida & $\begin{array}{l}\text { Fábio Tomaz (Radia- } \\
\text { lista Católico) e Dani- } \\
\text { lo Oliveira (Pastoral } \\
\text { Carcerária) }\end{array}$ & $\begin{array}{l}\text { Segunda a sex- } \\
\text { ta-feira }\end{array}$ & $12 \mathrm{~h} 15-14 \mathrm{~h}$ & $\begin{array}{l}\text { Interação com ouvintes e propagação da música } \\
\text { católica. }\end{array}$ & Entretenimento \\
\hline $\begin{array}{l}\text { Catequese em } \\
\text { Familia }\end{array}$ & $\begin{array}{l}\text { Solange Santos (Cate- } \\
\text { quista e Ministra da } \\
\text { Eucaristia) e Claudio } \\
\text { Lima (Ministro da } \\
\text { Eucaristia) }\end{array}$ & $\begin{array}{l}\text { Segunda a sá- } \\
\text { bado }\end{array}$ & $14 h-15 h$ & $\begin{array}{l}\text { Catequizar e evangelizar as famílias por meio da } \\
\text { reflexão do evangelho, leituras bíblicas e orações. }\end{array}$ & Confessional \\
\hline Terço da Divina & Grupos Paroquiais do & Segunda a sex- & $15 \mathrm{~h}$ & Rezar o Terço da Divina Misericórdia. & Confessional \\
\hline
\end{tabular}




\begin{tabular}{|c|c|c|c|c|c|}
\hline Misericórdia & $\begin{array}{l}\text { Terço da Divina Mise- } \\
\text { ricórdia }\end{array}$ & ta-feira & & & \\
\hline Canção Mariana & $\begin{array}{l}\text { Rodrigo Brito e Gil- } \\
\text { berto Pires }\end{array}$ & $\begin{array}{l}\text { Segunda a sex- } \\
\text { ta-feira }\end{array}$ & $15 h 30-17 h$ & $\begin{array}{l}\text { Busca propagar testemunhos de fé a Maria, cate- } \\
\text { quese, terço mariano e música mariana. }\end{array}$ & Confessional \\
\hline $\begin{array}{l}\text { Transmissão ao } \\
\text { vivo da novena e } \\
\text { missa direto do } \\
\text { Santuário Nossa } \\
\text { Senhora do Per- } \\
\text { pétuo Socorro }\end{array}$ & - & Terça-feira & $17 \mathrm{~h}-18 \mathrm{~h}$ & $\begin{array}{l}\text { Oportunizar que os ouvintes do interior, das ilhas e } \\
\text { aqueles impossibilitados de se deslocar até uma } \\
\text { igreja participem da missa. }\end{array}$ & Confessional \\
\hline $\begin{array}{l}\text { Terço da Divina } \\
\text { Providência } \\
+ \\
\text { Novena de São } \\
\text { José }\end{array}$ & $\begin{array}{l}\text { Pe. Fábio Rogério Pe- } \\
\text { reira e Marinete Pires }\end{array}$ & $\begin{array}{l}\text { Segunda, quar- } \\
\text { ta, quinta e sex- } \\
\text { ta-feira }\end{array}$ & $\begin{array}{l}17 \mathrm{~h} 15- \\
17 \mathrm{~h} 30\end{array}$ & $\begin{array}{l}\text { Rezar o terço da Divina Novena de São José, alcan- } \\
\text { çando os ouvintes do interior, das ilhas e aqueles } \\
\text { impossibilitados de se deslocarem até uma igreja ou } \\
\text { outro local onde possam fazer seus pedidos e inten- } \\
\text { ções. A Novena de São José alcança os ouvintes do } \\
\text { interior, das ilhas e aqueles impossibilitados de se } \\
\text { deslocarem até uma igreja ou local onde possam } \\
\text { fazer seus pedidos e intenções. }\end{array}$ & Confessional \\
\hline $\begin{array}{l}\text { Programa Viva a } \\
\text { Vida }\end{array}$ & $\begin{array}{l}\text { Pastoral da Criança } \\
\text { Nacional }\end{array}$ & Segunda-feira & $17 \mathrm{~h} 30-18 \mathrm{~h}$ & $\begin{array}{l}\text { Levar informações sobre saúde, educação infantil, } \\
\text { maternidade, gestação e transformação social. }\end{array}$ & Jornalistico \\
\hline $\begin{array}{l}\text { Circulo Bíblico } \\
\text { no Rádio }\end{array}$ & $\begin{array}{l}\text { Izabel Campos } \\
\text { (CEBS), Áurea Maria } \\
\text { (CEBS) e Maria do } \\
\text { Rosário (CEBS) }\end{array}$ & Quarta-feira & $17 \mathrm{~h} 30-18 \mathrm{~h}$ & $\begin{array}{l}\text { Evangelizar as famílias por meio da leitura orante, } \\
\text { meditação, oração, contemplação e ação. Também } \\
\text { busca dar a oportunidade aos ouvintes do interior, } \\
\text { das ilhas e aqueles impossibilitados de se desloca- } \\
\text { rem até uma igreja ou local onde acontece o círculo } \\
\text { bíblico. }\end{array}$ & Confessional \\
\hline Alegria e Fé & $\begin{array}{l}\text { Antônio Saraiva (Es- } \\
\text { cola Diaconal) e João } \\
\text { Pires (Músico de Ban- } \\
\text { da Católica) }\end{array}$ & $\begin{array}{l}\text { Segunda a sex- } \\
\text { ta-feira }\end{array}$ & $18 h-19 h$ & $\begin{array}{l}\text { Reflexão do evangelho do dia, interação e pedido de } \\
\text { oração pelos ouvintes. }\end{array}$ & Confessional \\
\hline $\begin{array}{l}\text { Jornal A Voz do } \\
\text { Brasil }\end{array}$ & \multicolumn{4}{|c|}{ Programação obrigatória produzida pela Empresa Brasil de Comunicação } & Jornalístico \\
\hline $\begin{array}{l}\text { Jornal Noticias } \\
\text { da Amazônia }\end{array}$ & $\begin{array}{l}\text { Produção da Rede } \\
\text { Notícias da Amazônia } \\
\text { (RNA) }\end{array}$ & $\begin{array}{l}\text { Segunda a sex- } \\
\text { ta-feira }\end{array}$ & $8 h-8 h 30$ & $\begin{array}{l}\text { Noticiário que divulga os acontecimentos da Igreja e } \\
\text { os fatos sociais, políticos e econômicos dos municí- } \\
\text { pios da Amazônia onde estão localizadas as emisso- } \\
\text { ras associadas. }\end{array}$ & Jornalístico \\
\hline Escola da Fé & Elton Favacho & $\begin{array}{l}\text { Segunda a sex- } \\
\text { ta-feira }\end{array}$ & $21 \mathrm{~h}-22 \mathrm{~h}$ & $\begin{array}{l}\text { Reviver em forma catequética os documentos, per- } \\
\text { sonalidades e acontecimentos da Igreja Católica. }\end{array}$ & $\begin{array}{l}\text { Confessional/ } \\
\text { Entretenimento }\end{array}$ \\
\hline
\end{tabular}




\begin{tabular}{|c|c|c|c|c|c|}
\hline Cura-me, Senhor & $\begin{array}{l}\text { Membros dos Movi- } \\
\text { mentos RCC, Amigos } \\
\text { Canção Nova Macapá } \\
\text { e Meninos de Fátima }\end{array}$ & $\begin{array}{c}\text { Segunda a sex- } \\
\text { ta-feira }\end{array}$ & $22 \mathrm{~h}-\mathrm{Oh}$ & $\begin{array}{l}\text { Levar a oração, meditação do evangelho e músicas } \\
\text { aos ouvintes que passam por algum tipo de proble- } \\
\text { ma pessoal. Cada dia da semana um grupo fica res- } \\
\text { ponsável pela produção e apresentação do progra- } \\
\text { ma. }\end{array}$ & Confessional \\
\hline $\begin{array}{l}\text { Vocação e Vida } \\
\text { Deus te Chama }\end{array}$ & $\begin{array}{l}\text { Irmão Josimar (Reli- } \\
\text { gioso), Irmã Carmelita } \\
\text { Luciana (Religiosa), } \\
\text { Anderson, Nilma e } \\
\text { José Menezes } \\
\text { Padre Edvaldo (Sa- } \\
\text { cerdote) e Seminaris- } \\
\text { tas do Seminário São } \\
\text { José }\end{array}$ & Sábado & $8 h-9 h$ & $\begin{array}{l}\text { Fazer reflexão e animação para divulgar e incentivar } \\
\text { a vida vocacional. Cada sábado do mês, um grupo } \\
\text { fica responsável pela produção e apresentação do } \\
\text { programa. }\end{array}$ & $\begin{array}{l}\text { Confessional/ } \\
\text { Entretenimento }\end{array}$ \\
\hline Catecriança & Cintia Batista & Sábado & $9 h-10 h$ & $\begin{array}{l}\text { Programa voltado para as crianças ouvintes da pro- } \\
\text { gramação. }\end{array}$ & Entretenimento \\
\hline Espaço MPB & $\begin{array}{l}\text { Edinete Moraes e } \\
\text { Cristina Homobono, } \\
\text { Josiane Calazans e } \\
\text { João Ataíde }\end{array}$ & Sábado & $10 h-12 h$ & $\begin{array}{l}\text { Valorização e divulgação da música popular brasi- } \\
\text { leira e amapaense (MPB e MPA) e entrevistas volta- } \\
\text { das para temas relacionados à cultura amapaense e } \\
\text { brasileira, música, poesia e leitura. }\end{array}$ & Entretenimento \\
\hline $\begin{array}{l}\text { Caminhos da } \\
\text { Amazônia }\end{array}$ & $\begin{array}{l}\text { Produzido pela Rede } \\
\text { de Notícias da Ama- } \\
\text { zônia - RNA }\end{array}$ & Sábado & $12 h-13 h$ & $\begin{array}{l}\text { Divulgar informações e orientações sobre a preser- } \\
\text { vação da Amazônia por meio de personagens do } \\
\text { cotidiano amazônida. }\end{array}$ & Jornalístico \\
\hline $\begin{array}{l}\text { Caminhos da } \\
\text { Missão }\end{array}$ & $\begin{array}{l}\text { Membros da Comuni- } \\
\text { dade - Infância e Ju- } \\
\text { ventude Missionária: } \\
\text { Angleson Pinheiro, } \\
\text { Marceli Coimbra e } \\
\text { Artur Diego }\end{array}$ & Sábado & $13 h 30-15 h$ & $\begin{array}{l}\text { Refletir a palavra e temas voltados para a missão na } \\
\text { infância, adolescência e juventude missionária; } \\
\text { também divulga ações e atividades do grupo que } \\
\text { acontecem na diocese e no mundo. }\end{array}$ & Confessional \\
\hline $\begin{array}{l}\text { Clube do Ouvin- } \\
\text { te Especial de } \\
\text { Sábado }\end{array}$ & Marinete Pires & Sábado & $15 h-17 h$ & $\begin{array}{l}\text { Uma continuidade do programa da semana, com } \\
\text { interação com o ouvinte e dando destaque para as } \\
\text { músicas católicas mais tocadas ao longo da semana. }\end{array}$ & Entretenimento \\
\hline $\begin{array}{l}\text { Pastoral Famili- } \\
\text { ar em Missão }\end{array}$ & $\begin{array}{l}\text { Os casais membros } \\
\text { da Pastoral Familiar: } \\
\text { Admilson e Mariza, } \\
\text { José Maria e Ana Vir- } \\
\text { ginia, Pena e France }\end{array}$ & Sábado & $17 \mathrm{~h}-18 \mathrm{~h} 30$ & $\begin{array}{l}\text { Levar reflexão sobre a vida familiar a partir de te- } \\
\text { mas do cotidiano da Igreja. Também divulga as a- } \\
\text { ções e atividades realizadas pela Pastoral Familiar } \\
\text { na cidade de Macapá e em todos os municipios, bem } \\
\text { como nas ilhas do estado do Pará. }\end{array}$ & $\begin{array}{l}\text { Jornalistico/ } \\
\text { Confessional }\end{array}$ \\
\hline
\end{tabular}




\begin{tabular}{|c|c|c|c|c|c|}
\hline $\begin{array}{l}\text { Aquarela Musi- } \\
\text { cal }\end{array}$ & $\begin{array}{l}\text { Graça Penafort (Pas- } \\
\text { com) e Luiz Tadeu } \\
\text { Magalhães }\end{array}$ & Sábado & $18 \mathrm{~h} 30-20 \mathrm{~h}$ & $\begin{array}{l}\text { Propagar a história de compositores de música eru- } \\
\text { dita, clássica e popular. }\end{array}$ & Entretenimento \\
\hline Rádio Saudade & $\begin{array}{l}\text { Fábio Tomaz, Dayse } \\
\text { Sá e Suellen Fagun- } \\
\text { des }\end{array}$ & Sábado & $20 h-23 h$ & $\begin{array}{l}\text { Compartilhar saudade e sentimento nostálgico por } \\
\text { meio da música antiga a partir da interação com o } \\
\text { ouvinte. }\end{array}$ & Entretenimento \\
\hline $\begin{array}{l}\text { Transmissão da } \\
\text { Missa Direto de } \\
\text { uma Paróquia }\end{array}$ & - & Domingo & $7 \mathrm{~h} 30-8 \mathrm{~h} 30$ & $\begin{array}{l}\text { Oportunizar aos ouvinte do interior, das ilhas e a- } \\
\text { quelas impossibilitado de se deslocar que partici- } \\
\text { pem da missa em alguma igreja. }\end{array}$ & Confessional \\
\hline Remix 100.5 FM & Músicas programadas & Domingo & $8 h 30-9 h$ & Propagar as músicas católicas a partir da mixagem. & Entretenimento \\
\hline \#Juventude & $\begin{array}{l}\text { Elizângela Picanço } \\
\text { (Focolares) }\end{array}$ & Domingo & $9 h-11 h$ & $\begin{array}{l}\text { Programação voltada para a juventude, levando in- } \\
\text { formações de interesse jovem, reflexão do evangelho } \\
\text { e informações dos acontecimentos na igreja voltados } \\
\text { para a juventude, católica ou não. }\end{array}$ & Entretenimento \\
\hline $\begin{array}{l}\text { Antenados São } \\
\text { José }\end{array}$ & $\begin{array}{l}\text { Elton Favacho, Eliel- } \\
\text { son Lacerda e João } \\
\text { Pires }\end{array}$ & Domingo & $11 \mathrm{~h}-12 \mathrm{~h}$ & $\begin{array}{l}\text { Propagação de bandas, cantores e projetos musicais } \\
\text { católicos. }\end{array}$ & Entretenimento \\
\hline Agita 100.5 & $\begin{array}{l}\text { Edineusa Matos (Lí- } \\
\text { der de Comunidade) } \\
\text { Alberto Santos (Ju- } \\
\text { ventude Missionária) }\end{array}$ & Domingo & $12 h-13 h 30$ & $\begin{array}{l}\text { Propagar ritmos musicais católicos, bem como levar } \\
\text { ao conhecimento dos ouvintes os mais diversos rit- } \\
\text { mos da música católica. }\end{array}$ & Entretenimento \\
\hline A Hora Santa & $\begin{array}{l}\text { Reginaldo Santos e } \\
\text { Antônio Santos } \\
\text { (Ministros da Eucaris- } \\
\text { tia) }\end{array}$ & Domingo & $13 h 30-15 h$ & $\begin{array}{l}\text { Busca levar a reflexão do evangelho e fazer intera- } \\
\text { ção com o ouvinte. }\end{array}$ & Entretenimento \\
\hline $\begin{array}{l}\text { Para Ver a Paz } \\
\text { Acontecer }\end{array}$ & $\begin{array}{l}\text { Nielton Trindade } \\
\text { Comunidade Católica } \\
\text { Shalom }\end{array}$ & Domingo & $16 h 30-18 h$ & $\begin{array}{l}\text { Reflexão dos temas tratado pela igreja sobre a paz e } \\
\text { interação com ouvinte. }\end{array}$ & Entretenimento \\
\hline $\begin{array}{l}\text { Transmissão ao } \\
\text { Vivo - Missa } \\
\text { Direto da Cate- } \\
\text { dral de São José } \\
\text { de Macapá }\end{array}$ & & Domingo & $19 h-20 h$ & $\begin{array}{l}\text { Oportunizar que os ouvintes do interior, das ilhas e } \\
\text { aqueles impossibilitados de se deslocar até uma } \\
\text { igreja participem da missa. }\end{array}$ & Confessional \\
\hline $\begin{array}{l}\text { Festival de Su- } \\
\text { cesso }\end{array}$ & $\begin{array}{l}\text { Casal Radialista Celso } \\
\text { Rabelo e Marleide } \\
\text { Lima }\end{array}$ & Domingo & $20 h-23 h$ & $\begin{array}{l}\text { Interação com o ouvinte e seleção de músicas de } \\
\text { estilos não católicos. }\end{array}$ & Entretenimento \\
\hline
\end{tabular}


Fonte: Elaborada com base nas informações do site da emissora e naquelas escutas da programação durante 4 meses no ano de 2019 